\title{
VEJO, ENTENDO, AJO: UM SILOGISMO TENAZ NA COMUNICAÇÃO ESTÉTICA*
}

\author{
Stéphane Huchet** \\ http://orcid.org/0000-0003-4102-6920 \\ st.huchet@gmail.com
}

RESUMO $O$ fato de a arte ter sido e ser ainda vinculada a uma ideia moral consolida a crença histórica na sua capacidade de determinar (re)ações a partir das proposições que ela destina ao público. A arte, sobretudo na fase moderna e contemporânea, possuiria a força singular de afetar o espectador segundo um mecanismo de "gozo" que garantiria como, ao ver, eu entenderia naquilo que olho uma motivação a agir no mundo para responder a uma injunção moral presente na obra. Para pensar essa crença, que interessa, em primeira instância, a compreensão do trabalho de muitos artistas, Hans-Robert Jauss providencia argumentos decisivos. As análises de Giorgio Agamben sobre a função da "liturgia" antiga revelam-se fundamentais, também, para cernir ainda mais intensamente o que está em jogo nessa crença na possibilidade de as obras terem um efeito moral mobilizador sobre aqueles que as recebem. Todavia, cabe a Jacques Rancière questionar se o gozo estético proporcionado por essa liturgia dispara verdadeiramente no espectador uma motivação a agir.

Palavras-chave arte, gozo, (re)ação, Jauss, Rancière, Agamben.

ABSTRACT The fact that art was and is still linked to a moral idea consolidates the historical belief in its ability to determine (re)actions from the propositions it destinates to the public. Art, especially in the modern and contemporary period, would have a unique strength to affect the viewer according

* Artigo submetido em 29/11/2019. Aceito em 04/08/2020.

** Universidade Federal de Minas Gerais. Belo Horizonte, MG, Brasil.

KRITERION, Belo Horizonte, nº 148, Abr./2021, p. 171-191 
to a mechanism of "enjoyment" (Jauss) which would ensure how, when I see, I would understand in this when I look at a motivation to act in the world to answer to a moral injunction present in the work. To investigate this belief, which concerns, in a first moment, the understanding of the work of many artists, Hans-Robert Jauss provides decisive arguments. Giorgio Agamben's analyses of the function of the ancient "liturgy" are fundamental, too, to identify with more intensity what is at stake in this belief in the possibility that the works have a mobilizing moral effect on those who receive them. However, it is up to Jacques Ranciere to question whether the aesthetical "enjoyment" provided by the liturgy truly triggers the spectator a motivation to act.

Keywords art, enjoyment, (re)action, Jauss, Rancière, Agamben.

Considerada proativa por muitos artistas e críticos, a arte encontra na relação entre história e política correspondências suscetíveis de contribuir para um adensamento e para uma complexificação de seu teor. Na genealogia do conceito de política realizada no livro intitulado "Entre o passado e o futuro" (Arendt, 1997), Hannah Arendt evoca de modo inevitável o imperativo marxista de fazer a história e de transformar o mundo por meio de uma realização da filosofia. Ela apresenta argumentos instigantes a esse respeito. Eles nos interessam porque permitem estabelecer, por extensão, analogias entre a evolução da agenda da filosofia e a evolução da agenda da arte na modernidade. A respeito do que pode interessar à arte, retiramos da leitura dos dois primeiros ensaios do livro ("O conceito de história" e "O que é a autoridade?") duas características: 1) a arte moderna, por meio do caráter muitas vezes experimental de suas práticas, confirmaria o primado dado ao "processo" produtivo, em detrimento do resultado a ser "contemplado"; 2) o processo de produção, ou de criação, sendo relativo a cada domínio em que ocorre, tende a fazer do "valor" do processo e do produto algo relativo ao contexto e à situação em que foram desencadeados.

Com efeito, a arte moderna confirma fortemente a tese arendtiana de uma total fragmentação dos mundos na modernidade, de uma multiplicidade cognitiva e simbólica resultando da implosão da tradição, de uma transformação do campo dos valores em campo aberto, singularizado pela escolha e pela construção própria a cada indivíduo. A paisagem epistêmica da pluralidade dos mundos ou, como dizia o curador suíço Harald Szeemann em 1972, das 
"mitologias individuais", autoriza-nos a considerar que a arte é, para esse autor, um campo de manifestação privilegiado. Se, como afirma Hannah Arendt, a modernidade epistemológica consiste menos na afirmação de um organon transcendental permanente e sólido do que num jogo de proposições em contínuo estado de fabricação; se, desde o século XVIII, a filosofia da natureza e da história geram saberes construídos, podemos afirmar por extensão que a arte também se tornou a cena em que cada obra fabrica uma proposição. Como atualizar a leitura de Hannah Arendt no contexto contemporâneo? Se o valor artístico não é mais absoluto, mas relativo, circunstancial, ele dá à arte a oportunidade de atestar o valor, de transformar potencialmente cada obra em afirmação, senão do valor, pelo menos de algum valor que se depreende dela. $\mathrm{Na}$ arte, a perda de um referencial transcendente e a relativização do valor conforme as condições e circunstâncias de sua enunciação dão chance para a sua construção mais intensa e menos extensa. Antes, porém, essas condições e circunstâncias artísticas permitem que se una as agendas da fabricação e da ação, já que a passagem do por que ao como, das coisas ao processo, criam as condições favoráveis ao ato de disparar no mundo e para o mundo processos implicitamente finalizados. Assim, a ação, que Hannah Arendt restringe à ideia de efemeridade e esgotamento no próprio acontecer, torna-se a fabricação de um artifício, de um produto - a proposição - que tem um início e um fim. A arte moderna sempre se pensou como ação, mas teleológica. A insistência no processo e na necessidade da ação envolve a ideia de que o artifício age, que ele pode ser pensado no âmbito estético como o análogo da ideia moderna de uma natureza e de uma história que se desenvolvem e tendem ao progresso, propiciando, assim, valores. O paradoxo, no entanto, é que é a probabilização epistemológica e crítica do valor que incentiva a criação das proposições, ou seja, trata-se de uma verdadeira teleologia da ação baseada nas premissas apresentadas na frase anterior.

À luz das análises de Hannah Arendt, não conseguimos silenciar nossa convicção de que a arte da grande época do modernismo triunfante e, hoje, um certo tipo de arte ativista "colaborativa" contemporânea, ${ }^{1}$ tentaram - e ainda tentam - dar sentido a um tipo de agir (micropolítico e estético) fugaz, mas capaz de redimir a contingência cotidiana das atividades humanas. A sacralidade da arte moderna se perdeu, mas a secularização decorrente de

1 Trata-se dos chamados "coletivos de artistas", cujo número cresceu muito no Brasil do início do século XXI. A dimensão coletiva de suas ações envolve tanto os próprios artistas, que procuram inventar uma arte mais anônima e pretensamente menos autoral, e o público convidado a entrar num processo de partilha com eles. Toda cidade brasileira possui "coletivos", como, por exemplo, o Grupo Poro, em Belo Horizonte; o grupo Gia (Grupo de Intervenção Ambiental), em Salvador, Bahia etc. 
um certo desmoronamento dos ideais utópicos não impede que sobrevivam algumas de suas mais significativas relíquias morais.

A presença da ideia de formação - Bildung - da humanidade através da arte atravessa um longo século XX que não deixa de se prolongar no início do XXI. As inúmeras vanguardas do início do século XX já transmitiam a ideia da força que a arte tem de agir, de ser uma potência ativa ou, para retomar o vocabulário de Hannah Arendt, de fabricar o valor para cumprir ou satisfazer um sentido histórico. A crença na possibilidade de a arte fabricar sentido e de projetar na história esse ideal caracteriza fortemente o tempo a que nos referimos. Esse ideal evidencia o fato de que, na modernidade, a condição política da arte está ligada à analogia entre a condição histórica da política e a condição histórica da arte. A arte pretende ser uma espécie de filosofia prática da história, ela pretende fabricar a história. Desde Piet Mondrian e Kasimir Malevic no início do século XX, com Joseph Beuys, meio século mais tarde, e, para falar de hoje, os artistas colaborativos, sempre se tratou de transformar os homens e a sociedade, de melhorá-los, de transformar suas condições de vida. Essa perspectiva política aproxima o artista do filósofo, quando ambos tentam trabalhar a transformação do (seu) conhecimento em princípio de ação, considerando-se detentores de uma legitimidade para esclarecer e despertar o público. Para resumir esse mecanismo de modo sintético, eu diria que o artista fabrica ou constrói um uso da arte que é um uso "político" da Ideia de arte. Isso envolve um jogo. No contexto da arte, o que poderíamos constatar a partir da leitura de Hannah Arendt (que não fala de arte, mas de história e de política)?

A história das ideias políticas mostra como é antigo o mecanismo que leva alguém, detentor de um saber específico, a pretender transformar seu conhecimento em princípio de governo. Esse tipo de gesto é iniciado, mais uma vez, por um filósofo, Platão, quando este se encontra perante a necessidade de pensar melhor a respeito da política. Hannah Arendt lembra como o desafio de pensar "As leis" significa pensar as condições para fazer do filósofo o governante ideal. Para isso, deve-se cernir o princípio legítimo de indução, comando e obediência, seja do especialista, que é objeto de confiança, seja do filósofo, cujo governo se deve ao fato de encarnar um tipo de ser diferente daqueles que lhe obedecem. Trata-se, lembra Hannah Arendt, de definir um saber o que fazer, ou seja, seu incontestável porquê. Em um certo momento, Platão precisou reorientar seu conhecimento das Ideias verdadeiras para a determinação de medidas de ação. Mas como ele o fez? De volta na caverna da existência humana, o filósofo tenta transformar para o uso dos mortais o que viu e compreendeu e o que o deixou tão perturbado. O conhecimento precisa ser levado aos leigos com cautela e com as devidas mediações. Essa adequação 
é uma espécie de diplomacia cognitiva que transforma as Ideias em medidas e normas e a filosofia em política. Isso é particularmente interessante uma vez que apresenta elementos para pensar a relação entre o artista e seu público.

Esse mecanismo gira em torno do uso das ideias (retiremos suas maiúsculas) por aquele (o filósofo ou o artista) que sua inteligência dos segredos do mundo ou das verdades escondidas aos anônimos coloca numa situação apropriada para construir uma relação serena entre esse conhecimento apurado e os "mortais". Na metafórica platônica, o filósofo (no nosso contexto, o artista) tem vocação a governar, da mesma forma como cabe ao marceneiro fabricar seus móveis... Ele conhece o aparato técnico de seu material. Transformar o teor do conhecimento em princípio de ação, transformar o conhecimento teórico em participação concreta e ativa, é o que muitos artistas propõem hoje. Um pouco como se passa, a partir do livro VI da "República", do sentido inicial das Ideias ao seu sentido de "bem" superior, essa transformação projeta um "bom para" ou um "apto a" de dentro de uma doutrina filosófica assim reorientada para o uso político. São as Ideias, transformadas em Bem, que inspiram o valor inerente à boa faculdade da ação. Na passagem da Ideia de arte para seu uso teleológico e empírico, patenteia-se uma espécie de virtude ativa e forja-se um princípio de aptidão para governar a Cidade. Esse ativismo demonstra a força imperativa desse pano de fundo, desse subsolo metafísicopolítico, dessa estratégia conceitual. Quando se pretende, como o pretendem hoje tantos artistas da vertente ativista colaborativa, despertar a consciência do público, fazer da arte uma prática capaz de nortear uma proposta interativa e intersubjetiva de tomada de consciência, o que está agindo é a crença no poder transformador, política e eticamente transformador e formador da arte. Nesse processo, a arte seria entendida como capaz de sensibilização moral. E essa última seria como que um primeiro passo, uma mediação necessária para alcançar um conjunto mais amplo de consequências no âmbito da vida social e, para confirmar o direcionamento desse conceito com Hannah Arendt, política. Tal mecanismo envolve a crença no fato de um certo tipo de razão - a do homo aestheticus - ser capaz de transformar o mundo e de realizar um ideal, mesmo que em escala micropolítica.

\section{Exemplaridade sensível}

Se nada pode reverter a crença social no poder do artista e na necessidade de sua existência, devemos, portanto, aprofundar o fato de que nada tampouco reverte um dado primordial, primeiro e soberano: a capacidade que a experiência estética, exemplificada pela experiência artística, teria de configurar um 
espaço de proposição e indução cuja finalidade seria moral. De que se trata? Para responder, o núcleo da experiência estética precisa ser investido de uma forma que o transforme em condição de possibilidade de algo mais amplo: o conhecimento sensivel de algumas orientações de caráter moral na arte. O "desinteresse" kantiano é muitas vezes interpretado como um conceito de desconexão total do Belo em relação a qualquer tipo de compromisso e engajamento. Ora, podemos escolher em Kant um outro conceito, o da Beleza aderente, por exemplo, evocado em sua terceira Crítica, por meio da qual os homens podem representar e apresentar para si, na imaginação produtiva, alguns fins racionais capazes de nortear seu desejo de contribuir, por meio da experiência estética, ao incremento de sua condição humana... A partir dessa extensão realmente "interessada", a experiência do Belo pode ser promissora e levar a consequências éticas e políticas.

Jean-Marie Schaeffer nos dá uma chave importante quando lembra que a Estética, como doutrina filosófica, serviu, no século XVIII, de espaço coordenador, articulador e unificante de duas vertentes da filosofia que precisavam ser mantidas unidas, a razão pura e a razão prática, representando respectivamente o entendimento e a ética. No momento de fundar a completude orgânica do sistema filosófico, a Estética, como aparato conceitual que pensa e concebe os termos da experiência de prazer (ou desprazer) suscitada no sujeito por tal ou tal dado da realidade, representou uma maneira de vincular subjetividade e humanidade. Segundo Schaeffer, a relação bipolar da experiência estética e da obra de arte com o conhecimento e com a moral (em Kant), com o sensível e com o conceito (em Hegel), garante a função disponibilizada pela filosofia para fundar sua unidade sistêmica. Por volta de 1790, com Kant, ter-se-ia sistematizado a vontade de uma nova completude ontológica, que encontraria na doutrina estética o espaço de reconciliação da subjetividade e da "universidade transcendental da humanidade" (Schaeffer, 2000 , p. 4). Isso coloca a experiência estética, portadora de um juízo reflexivo, num lugar de destaque, de liame, de motor, de indutora de comportamentos morais - um papel que ela continua tendo hoje nos meios artísticos que apostam muito mais na experiência estética do que na produção do objeto artístico. Sabemos também de que forma a arte moderna se caracterizou por uma potente introjeção de intenções e pretensões morais. A história da arte é um terreno privilegiado quando se trata de medir o poder atribuído a uma experiência que por muito tempo não foi chamada de "experiência estética", mas que já possuía os mecanismos posteriormente atribuídos a ela pela Estética filosófica. Podemos observar como, em diversos contextos epistêmicos, a arte foi um suporte da ação moral. Uma de suas condições costumava ser a existência e a valorização crítica de um patrimônio considerado modelo estético-moral. 
Um pequeno livro do historiador da arte Salvatore Settis, intitulado "Futuro del "classico", apresenta as formas e as funções do clássico na cultura ocidental por meio da consolidação e da sobrevivência de seus dois principais paradigmas: Grécia e Roma. Sem retraçar a dinâmica histórica que fez da Antiguidade e dos Anciãos o motor de uma certa evolução da arte até o século XIX, podemos remeter ao pequeno capítulo 9 do livro, no qual Settis lembra como, para os críticos, historiadores e artistas neoclássicos do século XVIII, a complexa e sinuosa relação dialética com os clássicos visava a

uma profunda renovação moral e política da sociedade por meio da arte. Esse
programa estava em perfeita harmonia com as reflexões dos ideólogos sobre a arte
como "tecnologia moral", mecanismo que solicita o sentimento e o desejo do público
[...], e que, portanto, é capaz de penetrar na consciência dos cidadãos para introduzir
novos modelos comportamentais (Settis, 2005, p. 78).

Settis lembra também que "a participação emotiva valia tanto, senão mais, do que um irrefutável raciocínio lógico" (Settis, 2005, p. 79). Reconhecemos aqui o solo histórico da arte como "tecnologia moral” (Settis, 2005, p. 78). Mas o que nos interessa é que a arte, como tecnologia moral, está historicamente apoiada sobre um determinado tipo de gestão do patrimônio artístico e da tradição clássica. Durante muitos séculos, com ênfase entre os séculos XV e XIX, a relação dialética com a tradição dos Antigos constituiu o território privilegiado de um uso simbólico, didático e pedagógico da arte. A vontade moral convocava - bem como se apoiava neles - os valores paradigmáticos e insuperáveis das obras, imagens e textos herdados da tradição, cuja atualidade era objeto de sucessivas relegitimações críticas. No fim do século XVIII, por exemplo, tanto as reflexões de um Claude-Henri Watelet a respeito das funções nacionais e morais da arte - consideradas pelo historiador Dominique Poulot como precursoras, antes da Revolução, da função pedagógica do museu (Poulot, 2008, p. 43) -, ${ }^{2}$ quanto as várias propostas de pedagogia institucional das artes, apresentadas por membros do Institut National des Sciences et des Arts, na fase de consolidação da Revolução, revelam que o que motivou a ação dos poderes públicos visando à formação moral de um público cidadão foi a existência de um patrimônio artístico. Nessa fase da história do patrimônio e de sua circulação institucional, já vemos como as noções de moral e de política se encontram articuladas dentro de uma aposta: ela consiste em pensar que

2 Poulot fala do colecionismo como modelo do museu público, o domínio privado do colecionador sendo "colocado sob o olhar de um público identificado com uma exigência moral". 
o homem culto, iniciado à alta cultura artística, se tornaria um sujeito mais harmonioso e mais integrado às legitimações do Estado e à vida comum.

Chegando na arte moderna, reparamos nela um amplo leque de experiências estéticas suscetíveis de satisfazer uma exigência moral graças a mecanismos de indução cuidadosamente trabalhados. Bastaria remeter aqui ao pensamento de pintores como Wassili Kandinsky, Paul Klee, Piet Mondrian, Kasimir Malevic, e tantos outros artistas de cunho construvista, no início do século XX, para entender como a arte dessa época veiculou um ideal moral absolutamente inédito. Sua singularidade reside no fato de querer ser moral sem, contudo, supor um imperativo categórico transmissível pela obra de arte, nem a possibilidade de transformá-la em crivo puramente racional. Ela, no entanto, seria propensa a motivar alguma forma de (re)ação, já que, segundo Jacques Rancière, a arte que ele qualifica de "crítica" não renunciou à crença em sua capacidade de antecipar seu efeito. Rancière, portanto, tem razão ao perguntar: "A que modelos de eficácia obedecem nossas expectativas e nossos juízos em matéria de política da arte?" (Rancière, 2012, p. 53). Segundo ele, ainda hoje, assim como no século XVIII, acreditaríamos no poder que exercem sobre nós os signos sensíveis dispostos por um autor em determinado estado, uma vez que somos fiéis ao modelo pedagógico da eficácia da arte para induzir reações. Se a ideia rancieriana da necessária conjugação das dimensões éticas, representativas e estéticas da arte para se garantir um mínimo impacto e efeito é importante, é porque ela tira a arte contemporânea das limitações da doutrina estética entendida como unilateral e, tradicionalmente, vista como suspensão "desinteressada" das relações e conexões. A Beleza aderente, para retomar a categoria kantiana, permite cernir um terreno em que os valores morais e (neo)representacionais podem colaborar com os valores propriamente estéticos. A ideia de reequilibrar a predominância dada pela estética filosófica ao desinteresse e à suspensão perceptiva por certos elementos próprios à dinâmica representacional e ética das imagens é fundamental na arte contemporânea e naquilo que ela pretende induzir no espectador.

Hans Robert Jauss, filósofo conhecido como teórico da recepção, fez em 1972 uma palestra muito instrutiva, demonstrando como a Estética filosófica entende os mecanismos de tal indução. Sua argumentação representa uma resposta implícita - e antecipada - à questão que Rancière levanta acerca dos modelos de eficácia aos quais obedecem nossas expectativas em termos de política da arte. Para Jauss, só o gozo estético justifica "a função social da arte e das disciplinas científicas a seu serviço" (Jauss, 2007, pp. 10-11). Jauss acredita que apenas o gozo seria capaz de colocar o receptor em uma posição adequada diante da função emancipadora da arte. E se essa função depende do alcance, 
pelo receptor, do nível suprassensorial e mental de reflexão estética, então é o gozo o criador de uma atmosfera adequada e da possibilidade de passagem a esse nível suprassensorial. A uma filosofia da arte que identifica no gozo estético uma forma de compensação burguesa ao "ascetismo na vida" (Jauss,

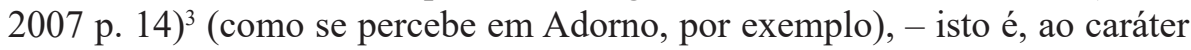
negativo, alienado e ideologicamente falso da vida -, Jauss opõe a certeza de que a melhor abertura, a melhor disposição à inteligência do teor de verdade e do teor social da arte se encontram em seu papel mediador e sensibilizador.

Jauss lembra com razão que foi por meio da autonomização da arte no século XIX - cujo ideal mais corriqueiro foi a arte pela arte - que a experiência estética, entendida como "gozo", foi relegada fora do domínio cognitivo ou da ação. Antes, a arte não se reservava um domínio tão exclusivo e excludente. Para Jauss, o gozo estético cria um sujeito "liberado pela imaginação de tudo aquilo que constitui a realidade constrangedora de seu cotidiano" (Jauss, 2007, p. 21). O gozo é a força que abre as portas para uma forma de ação. Ele permite que o sujeito seja liberado, não só por, não só de, mas, sobretudo, para... Citemos longamente o autor, pois a tese alcança o elemento que mais nos interessa aqui, o da motivação à ação, conforme a ordem de raciocínio que Rancière, trinta anos mais tarde, apresentará acerca da arte política. Jauss escreve:

[...] a liberação pela experiência estética pode ser realizada em três planos: a consciência, como atividade produtiva, cria um mundo que é sua obra própria; a consciência, como atividade receptiva, abarca a possibilidade de renovar sua percepção do mundo; enfim - e aqui, a experiência subjetiva deságua na experiência intersubjetiva -, a reflexão estética adere a um juízo requerido pela obra ou se identifica a normas de ação que ela esboça e cuja definição cabe a seus destinatários prosseguir (Jauss, 2007, p. 22). ${ }^{4}$

A mensagem é nítida, com uma definição clara de cada momento. No entanto, Jauss não diz que os três planos são necessariamente simultâneos. Com efeito, o segundo e o terceiro, isto é, a aisthesis e a catarsis, à diferença do primeiro, a poïesis - que ele associa a um dos "três conceitos chaves da tradição estética” (Jauss, 2007, p. 23) - interessam o receptor, que pode se dispor a agir se souber entrar em consonância com o teor de motivação contido na obra. "O homem pode ser [...] disposto, por meio da identificação estética, a assumir normas de comportamento social” (Jauss, 2007, p. 24). A disposição à ação que pode decorrer da experiência estética, enquanto gozo que libera a 
imaginação crítica, só é inteligível, na obra de Jauss, no horizonte da crítica que ele faz da recusa histórica de certos pensadores em reconhecer um valor ético e cognitivo na experiência estética. Ele culpa Agostinho, Rousseau, o século XIX (Jauss, 2007, p. 24) etc. Sua crítica ao pensamento estético de Herbert Marcuse (Jauss, 2007, p. 24) nos permite entender, por exemplo, como o mais grave na desqualificação da experiência estética como gozo consiste em atitudes geralmente hipermoralizantes que desqualificam o gozo em razão de seu pretenso e complacente compromisso com o idealismo e a indústria cultural. A desqualificação do gozo constitui um ataque exageradamente moralista - na verdade, ideológico - para negar qualquer possibilidade moral na obra apreendida através dele, já que o gozo, segundo Jauss, ao liberar a imaginação crítica, é plenamente legítimo para induzir uma ação diferenciada... Entre o banimento platônico da arte e a condenação marcusiana de uma experiência feliz que nos desviaria das tarefas críticas, existe um espaço para pensar o papel autenticamente social do gozo estético. Para Jauss, o trabalho de Jürgen Habermas, por exemplo, permite pensar o desafio de se criar uma ponte entre a experiência estética como contemplação solitária e essa mesma experiência como apelo para a comunicação de uma "nova solidariedade na ação" (Jauss, 2007, p. 33). O que importa é que a ponte, a abertura da obra ao seu prolongamento moral, a disposição do receptor numa atmosfera crítica capaz de motivar uma ação posterior etc., dependam do valor e da qualidade imanente da obra, de seu poder de construção de uma proposição impactante.

Para nos ajudar a entender essa atenção às virtudes próprias da obra e a sua capacidade de se transcender em uma projeção comunicativa, isto é, uma obra capaz de instituir um protocolo relacional com um sujeito solicitado para reagir ao estado do mundo, em nome de uma possível solidariedade social, Jauss recorre a Paul Valéry e à ideia de existência de uma função cognitiva da construção estética. Ele encontra no famoso diálogo "Eupalinos" (Jauss, 2007, p. 33) a convicção de que existe uma raiz comum para as operações da arte e para as empreiteiras do conhecimento. Se as operações da arte e as operações do conhecimento compartilham a necessidade de saber-construir, e se esse saber-construir significa um domínio da função cognitiva, todo o processo envolvido, tratando-se de arte, é o processo de uma "lógica imaginativa" (Jauss, 2007, p. 40), fórmula de Valéry no seu ensaio de 1894, O método de Leonardo da Vinci. Mas por que isso nos interessa? Porque é devido à lógica imaginativa de uma obra, bem como ao fato de que o gozo é gozo perante o valor manifesto de uma obra capaz de se transcender, internamente, num apelo comunicativo à ação, que as oposições entre ação e gozo, entre atitude meramente estética e prática moral, podem ser superadas. Inclusive, somente 
a integração, na experiência estética, de uma disposição e de uma motivação à ação, encontra-se inteiramente à altura do desafio da recepção e do estatuto moderno do sujeito receptor.

Pessoalmente, discordamos da leitura que Jauss faz da arte moderna como sendo uma arte de plena autonomia: o crítico alemão escreve que a arte moderna teria considerado heresia "todo didatismo, toda intenção de exemplaridade" (Jauss, 2007, p. 58). Um estudo consequente da história da arte - a respeito, por exemplo, dos mestres do abstracionismo do início do século XX - mostra claramente que o didatismo e a exemplaridade constituem verdadeiras condições para as obras de Kandinsky, Mondrian, Malevich, inclusive para os movimentos dadá, surrealista, independentemente das diferenças e das tensões aí inerentes. Jacques Rancière também desconstrói de maneira muito eficaz a ideia de uma arte moderna sem relações ou dinâmicas heterogêneas e heterônomas. Assim, para ele, a ideologia modernista, notadamente emblematizada pela reconstrução da evolução da pintura rumo as suas mais puras e essenciais condições de existência, buscou, em Clement Greenberg, montar um mito da autonomia. Esse mito nega e desconsidera os múltiplos e incontroláveis processos de contaminação, abertura, deslocamento, deslizamento, integração ao real - e do real -, etc., que caracterizaram a arte moderna desde o início do século XX. ${ }^{5}$ Se a arte moderna explorou e experimentou tantos processos de impurificação, complexificação e "desespecificação" etc., - num misto de entropia e "néguentropie", como dizia o paleontólogo e padre jesuíta Pierre Teilhard de Chardin $-{ }^{6}{ }^{6}$ ela foi, portanto, exemplar de uma arte capaz de criar elos das mais diversas espécies com seu exterior. Para nós, a arte moderna já almejou aquilo que Jauss propõe pensar como programa estético geral: o trabalho e a produção de modelos de identificação comunicativa. O que importa é que a arte saiba inventar esses modelos. Segundo o crítico,

[...] a experiência estética está amputada de sua função social primária principalmente se a relação do público com a obra de arte fica enclausurada no círculo vicioso que reenvia da experiência de si e vice-versa, e se ela não se abre àquela experiência do outro que se realiza desde sempre, na experiência artística, no nível da identificação estética espontânea que toca, que comove, que faz admirar, chorar ou rir por simpatia, e que só o esnobismo pode considerar trivial (Jauss, 2007, p. 58-59). ${ }^{7}$

5 Jacques Rancière fala disso em "Et tant pis pour les gens fatigués". Entretiens. Paris: Éditions Amsterdam, 2009, p. 348. Ver também a entrevista "Politics and Aesthetics". Angelaki, Vol. 8, Nr. 2. Ag. de 2003, p. 207.

6 Em meados do século XX, Teilhard de Chardin encontrou nesse neologismo uma maneira de contrapor sua potente visão teológica da criação contínua do universo no Cristo Cósmico ao princípio científico da entropia, vinda da termodinâmica de Carnot. A neg-entropia inverte a perda da informação, embutida no conceito de entropia, e aponta para a complexificação crescente do universo.

7 Quarta tese, enunciada em itálico no texto de Jauss. 
Ele acrescenta:

[...] é precisamente nesses fenômenos de identificação, e não no estado ulterior de uma reflexividade estética livre deles, que a arte transmite normas de ação - e de uma maneira que deixa ao homem uma margem de liberdade entre o imperativo das prescrições jurídicas e o constrangimento socializante exercido de maneira insensível pelas instituições (Jauss, 2007, p. 59).

Tal é a lógica da exemplaridade da arte: a experiência estética é capaz de transmitir normas singulares, porque imprescritíveis, a partir de recursos e mecanismos, eles mesmos imprescritíveis, de identificação de/a um modelo ou de/a uma causa. Nesse processo, tudo depende do gozo - nome que designa toda a cadeia da identificação, com prolongamento no estímulo à ação, um verdadeiro "interesse" -, e não apenas da possibilidade de sempre alcançar, de antemão, o nível suprassensorial da reflexão crítica por meio de uma mera tomada de consciência desconecta da imaginação. O gozo é a matriz que desencadeia todo o processo.

Por que a experiência estética do gozo, que pode interessar o sujeito e impulsioná-lo a possíveis normas de ação, é tão preciosa? Porque seu estatuto, independente das prescrições jurídicas e institucionais, pode constituir o motor do interesse a causas ou modelos extra-artísticos: "modelos heroicos, religiosos ou éticos podem ganhar muito em potência sugestiva se a identificação opera por meio da identificação estética" (Jauss, 2007, p. 61). Assim, em busca de antigos fundamentos e problematizando a relação da identificação estética com "a práxis comunicacional", Jauss observa como o cristianismo moderno está à origem de alguns deslocamentos que renovaram o campo da experiência estética: ao imaginário, o cristianismo teria substituído o exemplar; à purificação pela catarse, a compaixão que incita à ação solidária; e, ao prazer estético propiciado pela imitação, o mesmo cristianismo teria também substituído o apelativo, o convite a seguir o exemplo (Jauss, 2007, p. 62). Tais substituições cristãs, assim como a assunção do exemplar, da compaixão e da ação solidária, mostraram-se vinculadas a uma ideia de exemplaridade moral da arte. Encontramos aqui um pensamento que nos oferece os termos mais adequados para problematizar um ponto central de nosso propósito:

[...] se queremos saber como a experiência estética pode desaguar numa ação simbólica ou reorientada para a solidariedade, é particularmente interessante recorrermos aos conceitos de exemplaridade, de comunicação simpática e de apelativo (Jauss, 2007, p. 63). 
Jauss afirma que existem três tipos de identificação: a simpática, a catártica, a associativa. O que caracteriza esta última é o envolvimento participativo do espectador. Por exemplo, no contexto da tragédia, o espectador não fica inerte e distante de seu herói - figura preeminente, desde Aristóteles, no conjunto dos modelos de identificação. Alguma troca acontece. Assim como o artista contemporâneo e o receptor de sua obra, o ator e o espectador compartilham um jogo que põe cada um em situação de exercer e de assumir um papel, ao mesmo tempo que reconhece o papel dos outros, segundo modos de comunicação suscetíveis de orientar, por conseguinte, a própria vida social (Jauss, 2007, p. $65)$.

Não se pode exprimir melhor a singular combinação de participação (emocional, identificatória e suprassensorial) e de crença idealista na capacidade de a experiência estética motivar a ação, socializando assim, toda recepção! Essa é uma das chaves de legitimação da arte participativa, como se fala na arte desde os anos $1960 \ldots{ }^{8}$ Agora, se pensarmos nas mais variadas maneiras que a arte contemporânea inventou para envolver o espectador, nas práticas performáticas, ambientais, relacionais etc., entendemos por que os níveis de identificação propostos por Aristóteles têm tanta importância para Jauss já que, pensa ele, o herói pode ser melhor, pior, ou semelhante a mim. No primeiro caso, irei admirar o melhor. Irei permitir-me apreciar alguém que não reside no mesmo espaço que eu. No caso de um herói semelhante a mim, que habita o mesmo domínio que eu, e graças à simpatia que ele irá suscitar em mim, serei conduzido "à identificação moral e ao reconhecimento de uma conduta a seguir" (Jauss, 2007, p. 66). Para um receptor comum, um herói comum; para mim, um herói semelhante a mim: tal é a comunicação proporcional de empatia, a melhor chance para que eu me disponha a seguir "o exemplo".

$\mathrm{Na}$ busca de uma arte capaz de não renunciar à sua negatividade crítica frente à realidade, mas capaz também de restaurar, ao mesmo tempo, sua "função comunicativa" (Jauss, 2007, p. 72) e sua capacidade de criar "normas" democráticas, Jauss recorre ao valor paradigmático do juízo estético kantiano. Sua função comunicativa é efetiva se, para assumir seu papel de ponte entre razão teórica e razão prática, esfera racional e esfera moral, o juízo toma como referência ou guia algo exemplar, uma exemplaridade. A perspectiva é clara: a experiência estética é o padrão experimental da intersubjetividade comunicacional mais livre e mais produtiva que existe; ela não se determina em

8 O jogo que caracteriza a exposição e a recepção da arte é perfeitamente enquadrado nessa frase, que inclui também, já que se trata de jogo, a dimensão contextual e institucional do mundo da arte como mundo compartilhando, em todas as instâncias que o compõem, as mesmas regras de jogo. 
relação a uma "necessidade lógica" (Jauss, 2007, p. 76), ${ }^{9}$ mas é exemplar, pois cabe à definição e à função do juízo estético pretender ao universal, expor-se, oferecer-se, manifestar-se como candidato aos sufrágios. Em quê? Meu gosto, diz Kant, mesmo que não seja lógico nem racional, tende sempre a querer se tornar a regra dos outros; essa tendência leva-me a pô-lo na roda das trocas dialógicas, da comunicação.

Nisso, o sujeito experimenta um terreno desocupado, livre, imprescritível, para a problematização e argumentação do juízo. As trocas dialógicas suscitadas pelo ímpeto de compartilhar a experiência estética representam o melhor padrão da intersubjetividade social, da socialização; constituem funções sociais primárias. Jauss defende que, ao requerer a adesão de outrem, "esse juízo permite o estabelecimento coletivo de uma norma nova" (Jauss, 2007, p. 74). O juízo construído na experiência estética prepara os sujeitos para a arte da discussão, do consensus ou do dissensus. Sem dúvida, muitos artistas modernos e contemporâneos exploraram e exploram modos diversos de confirmar o papel determinante da arte, mostrando assim que seu estatuto mítico é a outra face de uma função experimental, fundadora de uma sociabilidade criativa que a torna moral. Nenhum artista, por mais lúdico que seja, renuncia a essa crença. A desacreditação significaria sua própria morte.

Jauss ainda faz uma ressalva. Se, na época de consolidação de sua autonomia, a arte moderna precisou instituir oposições entre inovação e tradição, ruptura e repetição, contestação e instituição, negação e afirmação, essas oposições não foram satisfatórias no momento de dar conta "das funções prática, comunicativa e normativa da arte antes e depois desse período" (Jauss, 2007, p. 77). A última tese apresentada por Jauss é exemplar do espírito dos artistas que procuram introduzir em suas obras, simultaneamente, um conteúdo moral e social. Jauss diz:

a experiência estética é amputada de suas funções sociais primárias enquanto a enclausuramos nas categorias da emancipação e da afirmação, da inovação e da reprodução, e enquanto não introduzimos as categorias intermediárias de identificação, exemplaridade e consensus aberto, essas categorias que, na experiência da arte, foram a base de toda atividade comunicacional, e que poderiam hoje fazer as artes saírem do impasse em que se deplorou tantas vezes vê-las engonçadas (Jauss, 2007, p. 77-78). ${ }^{10}$

9 Lemos na mesma página: "podemos pensar que, em caso de discussão sobre uma norma que é preciso estabelecer, a experiência estética permitiria estabelecer um consensus com mais facilidade que a lógica propedêutica."

10 Última tese, enunciada em itálico. 
Sem dúvida, esse texto, escrito em 1972, constitui hoje uma referência a ser meditada.

\section{In effectu}

Se é possível, portanto, que algo moral exista na experiência estética, como pensar que seu impacto determinaria o sujeito a agir ou levá-lo a (re)agir a seu teor? Jauss responde à questão, mas de uma maneira provavelmente idealista. Daí a pergunta rancieriana, que reabre uma das questões mais desafiadoras da arte: a de saber se um certo tipo de compreensão da obra de arte por parte do espectador deveria sempre desembocar em uma motivação à ação. Com efeito, não existe silogismo que declare: "Vejo, entendo, portanto, ajo". Segundo o "modelo pedagógico da eficácia da arte" (Rancière, 2012, p. 53), o problema provém da "pressuposição de um continuum sensível entre a produção de imagens, gestos ou palavras e a percepção de uma situação que empenhe os pensamentos, sentimentos e ações dos espectadores" (Rancière, 2012, p. 54).

Para entender esse modelo pedagógico, essa "tecnologia moral da arte" (Settis, 2005, p. 78), como escreveu Salvatore Settis a propósito dos projetos institucionais da Revolução Francesa, uma teoria da ação - indução, dedução, abdução - poderia nos ajudar, mas não adotamos uma grade semióticopragmática. Entretanto, os elementos pró-ativos da prática artística nunca deixarão de esbarrar no caráter não comprovável do silogismo que sustenta a crença nos poderes da imagem em determinar a agir socialmente... Por que, frente a uma obra de arte, uma imagem, uma encenação propositadamente orientada para questões sociais, políticas, por exemplo - e sabemos que a arte contemporânea está cheia desse tipo de proposições -, eu, espectador, iniciaria, posteriormente, de maneira quase automática, uma ação suscetível de modificar a realidade? Diante, por exemplo, de Trouxas ensanguentadas, de Artur Barrio, em 1970, diante das fotografias atuais de situações de conflitos feitas por Sophie Ristelhueber recentemente, nada garante que irei me tornar, imediatamente, um adversário ativo do regime militar que persegue os opositores políticos ou um adversário do Estado de Israel ou dos Estados Unidos. $\mathrm{O}$ que nos leva a pensar que o espectador que observa uma obra de arte ou que assiste a uma performance seria levado, de maneira quase automática, por determinação imperativa, a agir para atuar na ou em relação à situação evocada? Essa pergunta é rica em implicações porque problematiza o argumento daqueles que querem reaproximar a arte do domínio cotidiano da experiência, sob o pretexto de que nossa relação com as imagens de arte seria predominantemente passiva e que seria urgente reinventar um mecanismo em 
que o juízo reflexivo induziria um comportamento engajado. Decerto "a política própria à arte no regime estético consiste na elaboração do mundo sensível do anônimo" (Rancière, 2012, p. 65). Trata-se dos "modos do isso e do eu, do qual emergem os mundos próprios do nós político" (Rancière, 2012, p. 65). Mas, acrescenta Rancière, "na medida em que esse efeito passa pela ruptura estética, ele não se presta a nenhum cálculo determinável” (Rancière, 2012, p. 65). ${ }^{11}$ Diante dessa afirmação, nos perguntamos: se o efeito não pode ser calculado, ele pode ser construído? Rancière invoca o famoso conceito brechtiano de Verfremdung (o devir-estranho, normalmente traduzido por "distanciamento"): trata-se de um mecanismo em que "a estranheza sentida deveria dissolver-se na compreensão de suas razões", transmitindo, intacta, "sua potência de afeto para transformar essa compreensão em potência de revolta" (Rancière, 2012, p. 66). ${ }^{12} \mathrm{O}$ estranhamento produziria portanto um deslocamento-choque capaz de consolidar o poder reflexivo que determina a agir. Nesse mecanismo do teatro brechtiano, o mais importante seria

fundir num único e mesmo processo o choque estético das diferentes sensorialidades e a correção representativa dos comportamentos, a separação estética e a separação ética. Mas não há razão para que o choque de dois modos de sensorialidade se traduza em compreensão das razões das coisas, nem para que esta produza a decisão de mudar o mundo (Rancière, 2012, p. 66).

A segunda frase inicia a desconstrução. Rancière afirma que "esse efeito não pode ser uma transmissão calculável entre choque artístico sensível, tomada de consciência intelectual e mobilização política" (Rancière, 2012, p. 66). Esse comentário critica uma ilusão tenaz, neste caso, a ilusão transcendental contida na ideia que postula, como Jauss disse insistentemente, que existe uma relação transitiva entre perceber, entender e agir, entre choque artístico, tomada de consciência e mobilização. A crença na existência de uma tal relação só pode acontecer se o artista acreditar que a operação artística é dotada de algo que, em sua arqueologia do officium e nas suas reflexões sobre a "liturgia" e o rito, Giorgio Agamben chama de "efetualidade". Já que, hoje mais do que nunca, a permanência do mito do artista - o mito como força de estruturação e duração de uma representação social e simbólica - sustenta a possibilidade de lançar mão de estratégias operacionais ritualizadas, o rico e complexo teor da "liturgia" artística oferece um paradigma inédito. Em Agamben, encontramos

11 Tradução levemente modificada.

12 Tradução levemente modificada: no lugar da palavra "força" proposta pelo tradutor português, restabelecemos para a "puissance" do original francês a palavra "potência". Gozo jaussiano ou estranhamento-distanciamento brechtiano, mecanismos reto-verso da mesma ilusão transcendental? 
os conceitos que ajudam a entender melhor a crença nos efeitos da arte, já que ela explora recursos ao mesmo tempo simbólicos e práticos que geram a participação do espectador na dinâmica processual que lhe é submetida. O que diz Agamben?

$\mathrm{Na}$ medida em que na liturgia, trata-se de um "particular regime performativo peculiar da eficácia de uma actio [ação]" (Agamben, 2013, p. 46), o officium artístico encontra no paradigma do officium cristão - e ciceroniano - um termo de comparação produtivo. ${ }^{13}$ Assim, lembra Agamben, o mistério litúrgico, ao representar a paixão de Cristo, "realiza seus efeitos, de maneira que se pode dizer que a presença de Cristo coincide nele integralmente com sua efetualidade" (Agamben, 2013, p. 50); isso implica, porém, "uma transformação da ontologia, na qual substancialidade e eficácia parecem se identificar" (Agamben, 2013, p. 50).

Por meio do mito do artista, a potência da arte age como espaço institucional e social no qual o artista faz perdurar a força simbólica que ele assume explorar e manter - até que seja possível, às vezes, fazer da encenação ou da exposição do próprio corpo o rito mais favorável à essa perduração... Nesse sentido, a distinção ciceroniana entre arte in actu (que encontra em si própria seu fim) e arte in effectu (portadora de um impacto ativo além de sua enunciação) é fundamental, já que, na segunda categoria, "a operação se torna efetual, se dá realidade e consistência em um opus considerado, porém, não em si mesmo, mas primeiramente como effectus de uma operatio" (Agamben, 2013, p. 53). Como acrescenta Agamben, por meio da diferenciação entre práxis, poiësis aristotélica e várias outras categorias de arte em Cícero, a efetualidade certamente significa que "a efetuação da arte" tem um fim que não se encontra em uma "obra externa (como na poiësis), nem mesmo coincide [...] com a própria ação (como na práxis). Ela coincide, de fato, com o ato apenas na medida em que este é a efetuação (artis effectio) de uma arte" (Agamben, 2013, p. 54). Na perspectiva de tantas ações artísticas características da arte contemporânea, uma arte que não seja pensada como obra objetivada ou como

13 Mencionemos logo que não podemos somente restringir a realidade do officium às suas manifestações mais evidentemente performáticas e "litúrgicas", como, por exemplo, as encenações e outros ritos paracatólicos de Hermann Nitsch, ex-body artist austríaco, mas que devemos também estendê-lo a todo processo de exposição, que envolve sempre um rito, como sugeriu Germano Celant quando chamou a "instalação" de "cerimônia da exposição”. Cf. CELANT, G. "La machine visuelle. L'installation artistique et ses archétypes”. Kassel: Catágolo Documenta 7, 1982, p. XIII, XVII, XVIII. (Versão original Rassigna, Nr. 10 Junho de 1982, pp. 6-11). Trechos citados em BLISTENE, B.; DAVID, C., PACQUEMENT, A. (org.). "L'époque, la mode, la morale, la passion. Aspects de l'art d'aujourd'hui". Paris: Centre Georges Pompidou/Musée National d'Art Moderne, Catálogo de exposição, 21 de Maio-17 de Agosto de 1987, pp. 440-1. 
puro processo pelo processo - mas como efetualidade - revela-se um parâmetro fundamental. Agamben elucida:

[...] enquanto Aristóteles via realmente a obra (ergon) como telos da poiësis do artesão ou do artista, aqui [em Cícero], por meio do paradigma das artes performativas, como a dança e o teatro [...], o telos não é mais a obra mas a artis effectio (Agamben, 2013, p. 54-55).

Nessa frase, segue na tradução francesa um trecho que muito nos interessa e cuja ausência surpreende na edição brasileira:

É a partir da influência que um paradigma artístico pode ter exercido sobre a operatividade litúrgica que poderíamos colocar o problema inédito das relações entre arte e liturgia. Se, em Ambrósio [teólogo do século III], é o paradigma artístico que influencia o paradigma litúrgico, na modernidade, o contrário aconteceu e é a liturgia que providenciou o modelo da atividade do artista, por meio de um processo que alcançou sua plena consciência de si em Mallarmé, mas que pode ter encontrado seu apogeu nas performances contemporâneas (Agamben, 2012, p. 68). ${ }^{14}$

Citação crucial, central, fundamental. O silogismo transitivo que postula "vejo, entendo, ajo", sustenta-se na crença de uma potência - a arte - que se torna realidade por meio de sua própria operação em uma "ontologia energética-operativa" (Agamben, 2013, p. 60) que o artista saberia ritualizar como "liturgia". Trata-se para nós de entender a arte de caráter amplamente performativo, mas também a arte que pratica os rituais expositivos tradicionais, transformando-os em liturgias, como se fosse fundamentalmente motivada por uma economia (oikonomia) da efetualidade artística para a comunidade e o público. $\mathrm{O}$ estrato mais profundo que subjaz à ação artística é, portanto, a crença - a ilusão mantida viva (ficção?) - de que o officium encontra-se levado na "esfera da efetualidade e do effectus" (Agamben, 2013, p. 87). Para tomarmos duas polaridades extremas da arte moderna envolvidas em horizontes sociais, críticos e filosóficos bem diferenciados, seja o dadaísmo dos anos 1916, o neodadaísmo dos anos 1950, seja a produção de pintura monocromática de cunho espiritualista ou materialista, podemos afirmar que o artista, além de um simples desejo de agir, sempre necessita, em seu arcabouço, de uma crença na artis effectio e na conciliação de duas posições: ${ }^{15}$

14 A alusão a Mallarmé não nos permite silenciar o fato de que um dos artistas recentes mais envolvidos na "liturgia" artística, Marcel Broodthaers, identificou no poeta do Coup de dés o inventor da arte contemporânea. Cf. HUCHET, S. "No ar: os curtocircuitos alegóricos de Marcel Broodthaers". In: "27ª Bienal de São Paulo. Seminários". São Paulo e Rio de Janeiro: Fundação Bienal de São Paulo/Ed. Cobogo, 2008, pp. 41-56.

15 Acreditamos que essa crença continua sendo forte, mesmo no caso de coletivos de artistas que pensam que o fato de pendurar balões entre prédios ou de incentivar ações por meio de simples cartazes quase 
uma situação subjetiva e uma competência-dever que define "a legitimação (e o dever correlato) para cumprir certos atos em virtude de seu encargo ou de sua função" (Agamben, 2013, p. 92). Tratar-se-ia de uma visão solene a respeito do artista? Não necessariamente. De Mondrian e os mestres do abstracionismo a André Breton e a galáxia surrealista e dadá, passando por Barnett Newman e o envolvimento "sublime"; Yves Klein, vendedor de "zonas de sensibilidade pura"; Lygia Clark, artista-terapeuta em Paris nos anos 1970 etc., o leque de atitudes, posturas, poses, ao mesmo tempo existenciais e artísticas, é amplo, complexo, plural, polifacetado, diverso. Dele são testemunhas, por exemplo, duas figuras emblemáticas da arte contemporânea: o pop Andy Warhol e o neowagneriano Joseph Beuys emblematizaram, nas décadas de 1960 e 1970, duas possíveis - e não necessariamente opostas - posições de discurso dentro da liturgia.

A liturgia artística ritualiza a crença na faculdade de a arte disparar, através do gozo jaussiano, alguma recepção ativa e renovadora.

Passagem da mística à política: o artista, sob a vestimenta democrática, nunca deixa, portanto, de re(in)staurar a concepção e a produtividade mítica de sua função ou officium, já que ritual artístico e democracia não são em nada antinômicos e que a liberdade permitiu a coexistência histórica do neodandysmo cínico do criador das Brillo Boxes e Marylin (Warhol) e do neochamanismo holístico-ecológico de Joseph Beuys, que plantou 7 mil árvores na $7^{\text {a }}$ Documenta de Kassel, 1982. Poderíamos, inclusive, ler em toda a tradição duchampiana e pós-duchampiana, isto é, numa certa iconoclastia moderna, surpreendentes formas de ritualização - dentro da liturgia adequada - da tensão com os próprios rituais artísticos tradicionais. O que mais impressiona, quando se estuda atentamente o pensamento dos artistas modernos, é a ausência de dúvida quanto à capacidade de o officium, agenciador de ações e recursos dos mais diversos, alcançar suas metas sociais e morais, sobretudo por meio de um núcleo prático, de uma poiësis inventiva (o que não quer dizer que ela seja convincente do ponto de vista plástico e estético). Assim, a crença na arte como tecnologia moral recebe dessa imersão na lógica litúrgica do officium artístico uma nova luz. No entanto, um olhar desconstrutivo como o de Rancière nos leva naturalmente a desmontar a ilusão que a máquina "litúrgica" ritualiza de modo permanente. Com efeito, nada garante que a interrelação entre obra e público - pleiteada, desejada, encenada, agenciada - leve este último a intervir na ordem da ação (meta/micro)política. Na verdade, encontramos aí algo que 
diz respeito ao desafio da participação, termo que surgiu na arte há meio século, mas que poderia muito bem ser o termo adequado para remeter ao complexo leque de relações que os homens mantêm com as imagens e com a arte desde tempos imemoriais.

A crença num efeito da proposição artística, a encena litúrgica dos ritos que determinam a mediação estética - o que Jauss problematizou através do gozo -, apostam na performatividade do silogismo que Rancière identifica nas suas reflexões sobre a arte "política". Vejo, entendo e re(ajo). Mas, onde Jauss e Agamben afirmam que esses ritos são portadores de efeitos dos quais os espectadores raramente escapam, o filósofo francês vai além da questão da participação empática para desconstruir seus impensados. Para ele, a arte pretende muito mais do que pode realmente. Se são as virtualidades do agir artístico que motivam Jauss e Agamben, o que interessa Rancière, como bom desconstrutor irônico, é mostrar que a política das artes não passaria de uma aposta moral não sempre coroada de êxito.

Essa discussão interroga não só as mais fundamentais intenções artísticas e estéticas da arte na sua história, como também suas recentes reatualizações, notadamente no trabalho dos artistas que chamamos de "ativistas". Vale, portanto, investigar na filosofia da arte o que pode amparar uma crítica mais contundente do agir artístico quando este é, como hoje, motivado pela ideia, já histórica, de mudar a vida. Nesse sentido, tanto as perspectivas dadas por Hannah Arendt quanto por Rancière ao conceito de "político" são pertinentes para ressituar esses horizontes. Eles se querem portadores de injunções morais. O lema final seria: refaçamos as consciências e teremos um novo mundo. Tal é exatamente o sentido do silogismo. Resta crer nele...

\section{Referências}

AGAMBEN, G. “Opus Dei. Arqueologia do ofício”. Homo Sacer II, 5. São Paulo: Boitempo editorial, 2013.

$\overline{\text { Seuil. } 2012 .}$

. "Opus Dei. Archéologie de l'office”. Homo Sacer II, 5. Paris: éditions du

ARENDT, H. (1972). "Entre o passado e o futuro”. São Paulo: Perspectiva, 1997.

JAUSS, H. R. "Kleine Apologie der ästhetischen Erfahrung". Constanz : Verlangsanstalt, 1972. "Petite apologie de l'expérience esthétique", tradução para o francês de Claude Maillard, Paris : Éditions Allia, 2007.

POULOT, D. "Une histoire des musées de France. XVIIIè-XXè siècle". 2a. ed. Paris: La Découverte/Poche, 2008.

RANCIÈRE, J. (2008). "O espectador emancipado". São Paulo: WMF Martins Fontes, 2012. 
SCHAEFFER, J.-M. "Adieu à l'esthétique". Paris : PUF, Les essais du Collège International de Philosophie, 2000.

SETTIS, S. "Futuro del "classico". Torino: Giulio Einaudi Editore. 2004. "Le futur du classique", tradução para o francês de Jean-Luc Defromont, Paris: Éditions Liana Levi, 2005. 
